\title{
UNIVERSITY OF PENNSYLVANIA RADIOCARBON DATES XVIII
}

\author{
BARBARA LAWN
}

Department of Physics and University Museum

University of Pennsylvania, Philadelphia, Pennsylvania 19174

\section{INTRODUCTION}

This date list includes most of the archaeologic samples dated in this laboratory since publication of our last date list $(R, 1974, v 16, p$ 219-237), as well as some samples dated previously, which lacked adequate sample information. The BP ages are based on AD 1950, and have been calculated with the half-life value of $5568 \mathrm{yr}$. All samples were counted at least twice for periods of not less than $1000 \mathrm{~min}$ each. Errors quoted for each sample are derived from the measurement of the sample, the background, and several counts of our mid-19th century Oak sample, but do not include the half-life error. All samples were pretreated with $3 \mathrm{~N} \mathrm{HCl}$ and some, where noted, were given additional pretreatment with $2 \% \mathrm{NaOH}$ for the removal of possible humic acid contaminants.

Our mid-19th century calibration samples have an average age of $139 \mathrm{yr}$. When corrected for this age, they have ${ }^{14} \mathrm{C}$ contents equal to $95 \%$ of the NBS oxalic acid standard. The average ${ }^{13} \mathrm{C}$ relationship between the Oak standard and the NBS limestone standard \#20 is -25.7 $\pm 1.3 \%$ as measured on the Univ of Pennsylvania mass spectrograph.

The MASCA corrected dates, appearing in this date list, have been arrived at by applying appropriate correction factors to dates calculated with the 5730 half-life. For further explanation, see Univ of Pennsylvania Dates XVI (R, 1974, v 16, p 198-218) and Ralph et al, 1973.

I wish to thank Ray Costa and John Mayes for their careful work in processing these samples.

\section{SAMPLE DESCRIPTIONS \\ I. ARCHAEOLOGIC SAMPLES A. Europe}

\section{Czechoslovakia}

\section{Bohemian series}

Late Bronze age and Early Iron age samples from Bohemia, Czechoslovakia, especially selected and subm by Evžen Neustupný, Československá Akad Věd, Prague, Czechoslovakia, in an attempt to minimize discrepancies between traditional archaeol chronology and corrected radiocarbon dates.

\section{P-1902. Chodouny, Grave 7}

Charcoal, Sample 2, from Grave 7, belonging to Phase D of Reinecke's chronologic scheme for Central European Bronze age, in extensive cemetery of urn-graves of Late Bronze age, Lausitz culture, at Chodouny, N Bohemia, Litomeřice dist $\left(59^{\circ} 29^{\prime} \mathrm{N}, 14^{\circ} 16^{\prime} \mathrm{E}\right)$, coll by 
J Hrala. Comment: $\mathrm{NaOH}$ pretreatment. (EN): corrected date is 100 to $200 \mathrm{yr}$ earlier than traditional estimates. Such a shift in absolute chronology would help to explain gap resulting from even more radical shift, of same direction, at beginning of Central European Bronze age.

Dneboh-Hrada, $N$ Bohemia, Turnov dist $\left(50^{\circ} 32^{\prime} N, 15^{\circ} 2^{\prime} E\right)$. Samples coll 1957 by $\mathrm{E}$ Plesová from late phase of Lausitz culture of partially excavated Late Bronze age village.

P-1904. Pit 300g

$3000 \pm 50$

$1050 \mathrm{BC}$

MASCA corrected date: $1300 \pm 60 \mathrm{BC}$

Charcoal, Sample 4, from Pit 300g. Comment: $\mathrm{NaOH}$ pretreatment.

P-1905. Pit 355

$3030 \pm 60$

$1080 \mathrm{BC}$

MASCA corrected date: $1340-1370 \pm 70 \mathrm{BC}$

Charcoal, Sample 5, from Pit 355. Comment: NaOH pretreatment.

\section{P.1906. Radonice, Pit 1/61}

$3050 \pm 50$

$1100 \mathrm{BC}$

MASCA corrected date: $1370-1390 \pm 60 \mathrm{BC}$

Charcoal, Sample 6, in fill of piriform storage pit, asssoc with characteristic pottery and animal bones, from Late Bronze age village of Knovíz culture, NW Bohemia, Louny dist (55 $\left.23^{\prime} \mathrm{N}, 13^{\circ} 55^{\prime} \mathrm{E}\right)$. Samples coll by Evžen Neustupný (Bouzek et al, 1966).

General Comment (EN): P-1904-1906, all belong to same period immediately succeeding P-1902, and are 100 to $200 \mathrm{yr}$ earlier than usually expected. Other unpub dates for same period: LJ-2091: $2940 \pm 100$; LJ-2042: $2810 \pm$ 100; UCLA-1485-A: $2860 \pm 60$; UCLA-1485-B: $2900 \pm$ 60; UCLA-1485-C: $2885 \pm 60$, may suggest that P-1904-1906 cover earlier part of Hallstatt A.

\section{P.1907. Vikletice, Hut 23}

$780 \mathrm{BC}$

MASCA corrected date: $940-980 \pm 70 B C$

Charcoal, Sample 7 , in fill of pit in Hut 23, of large scale rescue operation at Vikletice, NW Bohemia, Chomutov dist $\left(50^{\circ} 20^{\prime} \mathrm{N}, 13^{\circ}\right.$ $24^{\prime}$ E) which has unearthed hundreds of objects from all periods of prehistory, including several clusters of semisubterranean houses, including Hut 23, of late (Stítary) phase of Knovíz culture (Hallstatt B 2) (Bouzek et al, 1966). Samples coll 1962 by Drahomír Koutecký. Comment: $\mathrm{NaOH}$ pretreatment. (EN): corrected date is ca $100 \mathrm{yr}$ earlier than archaeol estimates. It is in correct relationship with other dates of this series.

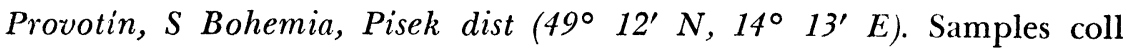
1971 by A Beneš. One of 2 barrows excavated at Provotín contained a $3 \mathrm{~m} \times 3 \mathrm{~m} \log$ cabin with uncremated internment and rich grave goods 
(more than 20 vessels, a bronze torque, iron knife, etc). Grave is typical of Hallstatt D period (early part) of Early Iron age.

\section{P-1908. Barrow 1}

Charcoal, Sample 8, Barrow No. 1, from uncharred beam in W part of grave chamber. Comment: $\mathrm{NaOH}$ pretreatment.

\section{P.1909. Barrow 1}

Charcoal, Sample 9, Barrow 1, from charred beam in NE corner of grave chamber. Comment: $\mathrm{NaOH}$ pretreatment.

General Comment (EN): P-1908 coincided with dates for Hallstatt A, common in barrows of this area. Barrow from which samples were taken was erected on deserted settlement of Hallstatt A period. P-1909 seems too late and dates are incompatible with each other, considering that they both came from same funerary structure sealed by body of barrow.

Manétin, $W$ Bohemia, Pizen dist $\left(50^{\circ} 1^{\prime} N, 13^{\circ} 15^{\prime} E\right)$. Site is extensive cemetery from Early Iron age consisting of 3 types of graves: barrows, cremations in pits, and inhumations in pits. Barrows form earliest group of finds (Hallstatt D, early part), cremation burials contain pottery and metal equipment (Hallstatt D, late), and inhumations are connected with La Tène culture. Samples coll 1967 by E Soudská.

\section{P.1910. Grave 80}

$1150 \pm 50$ AD 800

MASCA corrected date: AD 850-830 \pm 60

Charcoal, Sample 10, from Grave 80, found among stones surrounding barrow grave, which consisted of small pit with sherds and cremated bones.

\section{P-1913. Grave 164}

$2630 \pm 60$

$680 \mathrm{BC}$

MASCA corrected date: $820-840 \pm 70 \mathrm{BC}$

Charcoal, Sample 13, from fill of pit of Grave 164 (simple cremation) also containing an iron spear-head, 2 iron points, a bronze sheet, and hand-made pot. Comment: $\mathrm{NaOH}$ pretreatment.

\section{P-1914. Grave 173}

$2550 \pm 50$

$600 \mathrm{BC}$

MASCA corrected date: $790 \pm 60 \mathrm{BC}$

Charcoal, Sample 14, from Grave 173 (cremation in pit) containing hand-made pot, 2 arm-rings, and blue beads. Comment: $\mathrm{NaOH}$ pretreatment.

General Comment (EN): P-1910 was too small for $\mathrm{NaOH}$ pretreatment and may have contained contaminating rootlets. No evidence exists that site was inhabited in 9th century AD. Graves of P-1913 and -1914 are archaeol very similar and almost identical radiocarbon dates fit into 
relative sequence of this series, but their corrected age is unexpectedly high, suggesting error in traditional chronology (ca 6th century BC).

Kadan, NW Bohemia, Chomutov dist $\left(50^{\circ} 23^{\prime} N, 13^{\circ} 18^{\prime} E\right)$. Excavation at Kadan revealed semisubterranean houses from Hallstatt $D$ period and beginning of immediately following Early La Tène period. Excavation also unearthed $\mathrm{N}$-most extent of direct imports from Greece (Late Black Figure pottery). Samples coll 1968 by V Kruta.

\section{P-1915. Pit 12}

$$
1560 \pm 50
$$

\section{AD 390}

MASCA corrected date: $A D 410 \pm 60$

Charcoal, Sample 16, from fill of Pit 12, ca $1 \mathrm{~m}$ below modern surface. Comment: $\mathrm{NaOH}$ pretreatment. (EN): additional dates for same sample are MOC-27: $1560 \pm 80$, and MOC-34: $1580 \pm 80$ (personal commun). Because all 3 dates differ from expected age, finds from pit were inspected and found to contain undecorated sherds from possibly 5 th century AD.

\section{P.1916. House 13}

MASCA corrected date: $530,690-710 \pm 60 \mathrm{BC}$

Charcoal, Sample 17, House 13, from ca $1.4 \mathrm{~m}$ below modern surface. Comment: $\mathrm{NaOH}$ pretreatment. (EN): one of possible corrected dates $(530 \mathrm{BC})$ fits expectations exactly. Nearby archaeol feature contained fragment of imported Greek Black Figure pottery from end of 6th century BC. Date 530 BC suggests imported vessel was buried in Bohemia shortly after its production in Greece, not generations later as supposed by some archaeologists.

\section{Italy}

\section{B. Mediterranean}

\section{Casalini series}

Casalini (Artemesion), San Sosti, Italy $\left(39^{\circ} 35^{\prime} \mathrm{N}, 16^{\circ} 20^{\prime} \mathrm{E}\right)$ is medieval site on top of $\mathrm{mt}$ in Calabria. Ruined church or sanctuary of Middle age was only building visible before excavation, which was done to find Iron age or Greek deposits. Samples coll 1970 by Marianne Maaskant; subm by Froelich Rainey, Dir, Univ Mus, Univ Pennsylvania, Philadelphia.

\section{P.1724. Trench 1 D}

$$
1400 \pm 50
$$

\section{AD 550}

MASCA corrected date: $A D 590 \pm 60$

Charcoal from Trench $1 \mathrm{D}$, depth $1 \mathrm{~m}$.

$$
\text { P-1725. Trench } 1 \text { C, } 1 \text { 1200 } \pm \mathbf{5 0}
$$

Charcoal from Trench $1 \mathrm{C}, 1$, depth 70 to $115 \mathrm{~cm}$. 
P.1726. Trench 1 C, 2

$\mathbf{9 8 0} \pm \mathbf{5 0}$

AD 970

MASCA corrected date: $A D 1000 \pm 60$

Charcoal from Trench $1 \mathrm{C}$, 2, depth $1.15 \mathrm{~m}$. Comment: $\mathrm{NaOH}$ pretreatment.

General Comment (FR): deepest deposit was alongside stone reservoir for rainwater. Reversal of strata probably occurred during refilling around original reservoir excavation, hence, reversal of ${ }^{14} \mathrm{C}$ dates.

\section{P-1999. Casa San Paola}

$7900 \pm 100$

Casa San Paola, near Gravina, Apulia, S Italy $\left(40^{\circ} 50^{\prime} \mathrm{N}, 16^{\circ} 45^{\prime}\right.$ E) is a Neolithic site. Charcoal and soil, from Trench N-B-2-1, Lot 7 , depth $1.10 \mathrm{~m}$ in cave in wall of caliche. Sample coll 1972 by Nancy Whitney; subm by G F Bass, Univ Mus, Univ Pennsylvania, Philadelphia. Expected date: 3300 to 3500 Bс. Comment: date is beyond range of MASCA correction factors now available (Oct, 1974). See R, 1974, v 16, p 198-218 and Ralph et al (1973).

\section{Greece}

\section{Achilleion series}

Achilleion is a strat Neolithic site near Farsala, Thessaly, Greece $\left(39^{\circ} 17^{\prime} \mathrm{N}, 22^{\circ} 23^{\prime} \mathrm{E}\right)$. Excavation uncovered 3 consecutive Early Neolithic phases, Thessalian Pre-pottery, Frükeramikum and Proto-Sesklo, and 4 Middle Neolithic phases, Sesklo, exceptionally rich in finds, including house, ovens, 204 sculptures, offering table, etc. Phases are numbered from top. Samples coll 1973; subm by Marija Gimbutas, Univ California at Los Angeles, Los Angeles.

General Comment: dates in this series are beyond range of MASCA correction factors now available (Oct, 1974). See R, 1974, v 16, p 198-218 and Ralph et al (1973).

\section{P-2130. Sample 10}

$7080 \pm 90$

Charcoal, Sample 10, from SQ D, QD2, Level 7, Phase 1.

\section{BC}

\section{P.2128. Samples 13 and 15}

$7270 \pm 80$

5320 BC

Charcoal, Sample 13, Sq A, QD2-4, Level 8, and Sample 15, Sq A, QD3, Level 8, Phase 2.

\section{P-2125. Sample 74}

$6960 \pm 90$

Charcoal, Sample 74, from Sq B, QD4, Level 13, Phase 3a.

\section{P-2124. Sample 69}

$7090 \pm 90$

5140 BC

Charcoal, Sample 69, from Sq A, QD2, Level 14, Phase 3a. Comment: sample undersized, $96.01 \%$. 
P-2123. Sample 62

Charcoal, Sample 62, from Sq A, QD3, Level 14, Phase 3a. Comment: $\mathrm{NaOH}$ pretreatment.

P-2122. Sample 101

$7110 \pm 90$

5160 BC

Charcoal, sample 101, from Sq B, QD2, Level 16, Phase 3b.

P-2121. Sample 98

$7180 \pm 90$

5230 BC

Charcoal, Sample 98, from Sq B, QD2, Level 17, Phase 3b. Comment: sample undersized, $88.89 \%$.

P-2120. Sample 88

$7340 \pm 70$

Charcoal, Sample 88, from Sq A, QD1, Level 18, Phase 4.

P-2117. Sample 113

5390 вC

Charcoal, Sample 113, from Sq A, QD1, Level 26, Phase 6.

$7270 \pm 80$

5320 BC

P-2118. Sample 115

$7470 \pm 80$

5520 BC

Charcoal, Sample 115, from Sq B, QD2, Level 26, Phase 6.

\section{Franchthi Cave series}

Franchthi Cave $\left(37^{\circ} 26^{\prime} \mathrm{N}, 23^{\circ} 8^{\prime} \mathrm{E}\right.$ ) is near $\mathrm{W}$ tip of high, rugged headland, directly across bay from village of Koilada near Porto Cheli in S Argolid, Peloponnese, Greece. Site is especially important for its apparently continuous strat sequence from Late Paleolithic through Mesolithic and the critical transition to Neolithic. There are no strat prehistoric remains beyond Late Neolithic. Samples coll 1973; subm by $\mathrm{T} \mathrm{W}$ Jacobson, Indiana Univ, Bloomington, and $\mathrm{M} \mathrm{H}$ Jameson, Univ Mus, Univ Pennsylvania, Philadephia (Jacobsen, 1968; 1969a, 1969b, 1969c; 1973). For additional dates for this site, see R, 1971, v 13, p 364-367 and R, 1974, v 16, p 219-237.

General Comment: dates in this series are beyond range of MASCA correction factors now available (Oct, 1974). See R, 1974, v 16, p 198-218 and Ralph et al (1973).

\section{P-2093. F/A Balk, Unit 129S}

$6940 \pm 90$

Charcoal mixed with soil from F/A Balk, Unit 129S, relatively thin gray occupation layer, overlying P-1526, $8022 \pm 76$ and P-1527, $7897 \pm$ 88 (R, 1971, v 13, p 366). Expected date: late Early Neolithic.

\section{P-2094. F/A Balk, Unit 143S}

$7930 \pm 100$

Charcoal mixed with sediments from F/A Balk, Unit 143S, near middle of relatively thick light gray occupation layer, below P-2093 (above). 
P-2095. F/A Balk, Unit 146S

Charcoal mixed with sediments from F/A Balk, Unit 146S, at base of relatively thick gray occupation layer. Below P-2094 (above).

\section{P-2102. H-1, Quad B, Unit 126}

$9290 \pm 100$

Charcoal mixed with sediments from H-1, Quad B, Unit 126, hearth deposit in reddish brown occupation layer, below P-1665, $9477 \pm 134$, and P-1666, $8742 \pm 114(\mathrm{R}, 1971, \mathrm{v} 13, \mathrm{p} 366)$. Date expected to be Mesolithic.

\section{P-2103. H-1, Quad B, Unit 139}

$9300 \pm 100$

Charcoal mixed with sediments from H-1, Quad B, Unit 139, hearth deposit in reddish brown occupation layer, below P-2102 (above). Expected date: Mesolithic.

\section{P-2104. H-1, Quad B, Unit 139}

$9270 \pm 110$ 7320 BC

Charcoal from H-1, Quad B, Unit 139, coll by flotation in watersieving device using mixture of fresh and sea water (Jacobsen, 1973, p 57; French, 1971). Date expected to be Mesolithic and comparable to P-2103 (above). Comment: $\mathrm{NaOH}$ pretreatment.

\section{P-2096. F/A Balk, Unit 177N}

$8710 \pm 100$

Charcoal mixed with sediments from F/A Balk, Unit $177 \mathrm{~N}$, near top of layer with considerable crushed shell and animal bone, below, P-2095 (above). Expected date: Mesolithic, earlier than P-1526, $8022 \pm$ 76 (R, 1971, v 13, p 366) and comparable to P-2106 and -2107 (cf). Comment: $\mathrm{NaOH}$ pretreatment.

\section{P-2106. F/A Balk, Unit 177N}

$8730 \pm 90$

Charcoal from B/A Balk, Unit $177 \mathrm{~N}$, coll by flotation in watersieving device (see P-2104, above). Expected date: Mesolithic, earlier than P-1526, $8022 \pm 76(\mathrm{R}, 1971, \mathrm{v} 13, \mathrm{p} 366)$ and comparable to P-2096 (above) and P-2107 (cf). Comment: $\mathrm{NaOH}$ pretreatment.

\section{P-2107. F/A Balk, Unit 177N}

$8530 \pm 90$

Charcoal from F/A Balk, Unit $177 \mathrm{~N}$, coll by hand sorting among fine residue settling at bottom of sieve box, rather than flotation (see P-2104, above). Date expected to be Mesolithic, earlier than P-1526, $8022 \pm 75(\mathrm{R}, 1971, \mathrm{v} \mathrm{13}, \mathrm{p} 366)$ and comparable to P-2096 and -2106 (above). Comment: $\mathrm{NaOH}$ pretreatment. 


\section{P-2097. F/A Balk, Unit 197N}

$9150 \pm 100$

$7200 \mathrm{BC}$

Charcoal mixed with sediments from F/A Balk, Unit $197 \mathrm{~N}$, small hearth near base of rocky reddish occupation layer, below P-2096, -2106, and -2107 (above). Date expected to be Mesolithic.

P-2108. F/A Balk, Unit 218N

$9250 \pm 120$

7300 вС

Charcoal from F/A Balk, Unit 218N, hearth deposit in dark brown occupation layer coll by flotation in water-sieving device (see P-2104, above). Expected date: Mesolithic. Comment: $\mathrm{NaOH}$ pretreatment.

\section{Halieis}

Ancient city of Halieis is near modern village of Porto Cheli in S Argolid, Peloponnese, Greece. Site is partially submerged in shallow water. Wood id by R C Koeppen, Forest Prod Lab, U S Dept Agric, Madison, Wisconsin. Samples coll 1973 under water and subm by M H Jameson, Univ Mus, Univ Pennsylvania, Philadelphia (1969, 1973).

\section{P-2064. Sample 1}

$1570 \pm 50$

$$
\text { AD } 380
$$

MASCA corrected date: $A D 400 \pm 60$

Wood (Pinus sp) from Temple of Apollo, beneath floor, now ca-2m. Comment (MHJ): date probably later than destruction of temple, as there was Roman occupation in 4th century AD.

\section{P.2065. Sample 2}

$3110 \pm 50$

$1160 \mathrm{BC}$

MASCA corrected date: $1460-1480 \pm 60 B C$

Wood (Abies sp) from area enclosed by city walls, in possible harbor, under $2 \mathrm{~m}$ mud, $-4.5 \mathrm{~m}$.

P-2066. Sample 3

$2510 \pm 50$

$560 \mathrm{BC}$

MASCA corrected date: $780 \pm 60 \mathrm{BC}$

Charcoal (Pistacea sp) from beneath tile fall of final destruction of building, in middle room. Possible fragments from single roof beam, under ca $.3 \mathrm{~m}$ mud, ca $-1.75 \mathrm{~m}$. Comment: $\mathrm{NaOH}$ pretreatment.

\section{P.2067. Sample 4}

$2460 \pm 60$

$510 \mathrm{BC}$

MASCA corrected date: $660-730 \pm 70 \mathrm{BC}$

Charcoal, hard wood (perhaps Olea sp) from occupation level of middle room of temple under $.3 \mathrm{~m}$ mud, $\mathrm{ca}-1.75 \mathrm{~m}$.

\section{P-2098. Olive pits}

$$
1680 \pm 50
$$

\section{AD 270}

MASCA corrected date: $A D 280 \pm 60$

Stones (Olea europa) and possibly other fruit stones and nut shells from under rubble wall $\mathrm{N}$ of city wall, $-4.85 \mathrm{~m}$. From same area as P-2065 (above). 
P-2099.

$$
1820 \pm 50
$$

AD 130

MASCA corrected date: $A D 150 \pm 60$

Charcoal lumps separated from sample P-2098 (above).

\section{P.1784. Kato Zakro}

MASCA corrected date: $1110 \pm 70 \mathrm{BC}$

Charcoal from Kato Zakro, coast of E Crete $\left(35^{\circ} 10^{\prime} \mathrm{N}, 26^{\circ} 15^{\prime} \mathrm{E}\right)$, from NE entrance of palace believed to be MM IIIB to LM IA. Sample coll 1969 by Platon (1971), Univ Thessaloniki, Greece; subm by Leon Pomerance. Comment: $\mathrm{NaOH}$ pretreatment. (NEP): date expected to be 1600 to 1500 BC, based on manifold correspondence with Egypt and Orient.

\section{Near East}

1. Egypt

P-2049. Nile Delta

$5010 \pm 70$

3060 BC

$M A S C A$ corrected date: $3780 \pm 90 B C$

Carbonaceous silt enclosing skull of Hippopotamus amphibus, Nmost occurrence in Nile valley, from Nile Delta, Egypt $\left(30^{\circ} 56^{\prime} \mathrm{N}, 31^{\circ}\right.$ $57^{\circ} \mathrm{E}$ ). Sample coll from excavation $4 \mathrm{~m}$ below surface by Darwish Alfar, dir Geol Mus Cairo, Egypt; subm by Robert Giegengack. Comment: $\mathrm{NaOH}$ pretreatment.

\section{Turkey}

\section{P-2041. Acem Höyük}

Charcoal from storage building contemporary with palace at Acem Höyük, a large Bronze age mound NW of Aksaray in central Turkey $\left(38^{\circ} 30^{\prime} \mathrm{N}, 33^{\circ} 55^{\prime} \mathrm{E}\right)$. Sample coll 1971 by Nimet Özgüç, Univ Ankara, Turkey; subm by M J Mellink (Özgüç, 1968). For additional dates see: $\mathrm{P}-1555,3611 \pm 49$ and P-1595, $3391 \pm 58$ (R, 1971, v 13, p 371-372). Comment: $\mathrm{NaOH}$ pretreatment.

\section{Aphrodisias series}

Aphrodisias, Turkey $\left(37^{\circ} 43^{\prime} \mathrm{N}, 28^{\circ} 48^{\prime} \mathrm{E}\right)$ is ca $153 \mathrm{~km}$ SE of Izmir and $129 \mathrm{~km} \mathrm{E}$ of ancient port of Miletus. Samples are from "Acropolis" and "Pekmez" mounds within larger area enclosed by Hellenistic/Roman walls of later classical site. "Acropolis" mound consists of Early and Middle Bronze age levels and evidence of later periods up to Ottoman times. "Pekmez" mound to $\mathrm{W}$ consists of Chalcolithic levels overlain by Early Bronze Age I and II materials, as well as more recent materials. Samples coll 1967 and 1970; subm by Karen Flinn and Barbara Kadish, New York Univ, New York (Kadish, 1969, 1971). For additional dates see $R, 1971$, v 13, p 369-371. 
"Acropolis" mound

P-1774. Trench 3, Unit 228

$3800 \pm 60$

MASCA corrected date: $2190,2230-2290 \pm 70 B C$

Wood charcoal from hearth pit in Rm 2, Structure A, Complex II.

\section{P-1775. Trench 3, Unit 228}

$\mathbf{3 8 0 0} \pm 50$

M ASCA corrected date. $2190,2230-2290+60$ BC

Wood charcoal from bottom of hearth pit in $\mathrm{Rm} \mathrm{2,} \mathrm{Structure} \mathrm{A,}$ Complex II. Comment: $\mathrm{NaOH}$ pretreatment.

"Pekmez" mound

\section{P.2029. Trench 2, Test Trench B}

$M A S C A$ corrected date: $4830 \pm 90 B C$

Charcoal, Unit 1589d, from lens of heavily blackened earth. Depth $-6.55 \mathrm{~m}$ below subdatum. Comment: $\mathrm{NaOH}$ pretreatment. (KF \& BK): pottery of this level compares typologically with Late Chalcolithic period at Beycesultan; artifacts are similar to those of Chalcolithic Levels XVI, $\mathrm{XV}$, and XII at Mersin.

\section{P-2030. Trench 2, Test Trench B 2910 BC \\ MASCA corrected date: $3690 \pm 90 \mathrm{BC}$}

Charcoal, Unit 1589d, from lens of heavily blackened earth. Depth $-6.55 \mathrm{~m}$ below subdatum. Comment (KF \& $\mathrm{BK})$ : no $\mathrm{NaOH}$ pretreatment may account for different date from P-2029 (above).

\section{P.2031, Trench 2, Test Trench B \\ MASCA corrected date: $4100,4180 \pm 80 \mathrm{BC}$}

Ash and wood charcoal, Unit 1599a and b, from clayey, gray-brown earth. Depth $-7.97 \mathrm{~m}$ below subdatum.

\section{P-2040. Sakyol, Pulur}

$4610 \pm 70$

\section{BC}

$M A S C A$ corrected date: $3390,3440 \pm 80 B C$

Charcoal from Level XI, Sakyol, Pulur, Keban area, E Turkey $\left(38^{\circ} 52^{\prime} \mathrm{N}, 39^{\circ} 7^{\prime} \mathrm{E}\right)$ ca $45 \mathrm{~km}$ NW of Elâzig. Coll 1970 by Hamit Koşay (1970), Ethnographic Mus, Ankara, Turkey; subm by M J Mellink. Expected date: Early Bronze age, 1st half of 3rd millennium BC.

\section{Pakistan}

\section{Middle East}

\section{Gumla series}

Gumla is a low, Bronze age mound between village of Gumla to $\mathrm{N}$ and Garhi Hayat to S, Dera Ismail Khan Dist, W Pakistan $\left(31^{\circ} 44^{\prime}\right.$ $\left.\mathrm{N}, 70^{\circ} 47^{\prime} \mathrm{E}\right)$. Samples coll 1971 and subm by A H Dani, Univ Islamabad, Pakistan (1973). 
P.1810. Circle Grave 1

MASCA corrected date: $3110-3140 \pm 70 \mathrm{BC}$

Charcoal, Sample 1 from Circle Grave 1, Period V, found with human bones. Comment: $\mathrm{NaOH}$ pretreatment. (AHD): expected date: 1600 to 2100 BC.

\section{$\begin{array}{ll}\text { P.1812. Trench BO, Layer } 11 & \mathbf{4 0 8 0} \pm 70 \\ \mathbf{2 1 3 0} & \mathbf{B C}\end{array}$ \\ MASCA corrected date: $2700,2740,2820 \pm 80 \mathrm{BC}$}

Charcoal, Sample 3, from Trench BO, Layer 11, Period II. Comment: $\mathrm{NaOH}$ pretreatment. (AHD): expected date: 3000 to $3500 \mathrm{BC}$.

\section{P.1882. Location AO, Stratum 11}

$4210 \pm 150$

MASCA corrected date: $2930-2950 \pm 160 \mathrm{BC}$

Charcoal from Loc AO, Stratum 11. Comments: sample undersized for Univ Pennsylvania counters; gas was sent to Isotopes, Inc for counting as I-6694 $(85.9 \%$ in Isotopes counter). (AHD): expected date: 3000 to 3500 BC.

General Comment (AHD): much earlier dates expected for P-1812 and -1882 and much later dates for P-1810 and -1813 (cf).

\section{P.1813. Hathala}

$4040 \pm 60$ 2090 BC

MASCA corrected date: $2630-2680 \pm 70 B C$

Hathala is a Bronze age mound, ca $27.4 \mathrm{~km} \mathrm{~S}$ of Tank, Dera Ismail Khan Dist, W Pakistan $\left(32^{\circ} 1^{\prime} \mathrm{N}, 70^{\circ} 32^{\prime} \mathrm{E}\right)$. Sample consisted of charcoal and ash mixed with earth from Trench Y, Layer 2; coll 1971 and subm by A H Dani, Univ Islamabad, Pakistan (1973). Comment (AHD): much later date expected: 1600 to $2100 \mathrm{BC}$.

$$
\text { E. Africa }
$$

\section{Cameroon}

\section{Douloumi series}

Douloumi is Iron age mound with ca $4 \mathrm{~m}$ cultural strat, on Lake Douloumi in N Cameroon $\left(9^{\circ} 12^{\prime} \mathrm{N}, 13^{\circ} 39^{\prime} \mathrm{E}\right)$. Samples coll 1969 by Frank Bartell; subm by N C David, Univ College London, England. For additional dates from site, see: P-1761, $1089 \pm 41$; P-1763, $1074 \pm$ 47; and P-1764, $1412 \pm 50$ (R, 1973, v 15, p 376-377).

\section{P-1760. Strat Units 3 and $4 \quad$ AD 1730}

$$
\mathbf{2 2 0} \pm \mathbf{5 0}
$$

MASCA corrected date: $A D 1640 \pm 60$

Charcoal and soil from Strat Units 3 and 4 of 2nd arbitrary level of Iron age assemblage. Comment: $\mathrm{NaOH}$ pretreatment. 


\section{P-1762. Strat Units 15 and 16}

MASCA corrected date: $A D 950 \pm 60$

Charcoal and soil from Strat Units 15 and 16 of 8th arbitrary level of Iron age assemblage.

$$
\text { F. Arctic }
$$

\section{Alaska}

$$
1610 \pm 80
$$

P-2090. St Lawrence I Eskimo cadaver AD 340

$M A S C A$ corrected date: $A D$ 390-370 \pm 90

Muscle tissue from leg and abdominal cavity of frozen human body washed out of cliff face by landslide in area of Kialegak SE Cape, St Lawrence I, Alaska $\left(63^{\circ} 30^{\prime} \mathrm{N}, 169^{\circ} 20^{\prime} \mathrm{W}\right)$. Body was in tightly flexed position, with tattoo on dorsal aspect of lower right forearm, consisting of alternating pattern of lines and dots. Sample coll May 1973 by Z A Bradley, Natl Park Service; subm by M R Zimmerman, Depts Pathol \& Anthropol, Univ Pennsylvania, Philadelphia. Comment: after normal acid pretreatment, sample was put in oven $\left(110^{\circ} \mathrm{C}\right)$; rather than drying, sample became gelatinous. It was then pyrolyzed in a $\mathrm{N}_{2}$ atm before combustion. After pyrolysis, sample was too small for Univ Pennsylvania counters; it was sent to Isotopes, Inc for processing and counting. A better procedure for handling such a sample would have been first $\mathrm{N}_{2}$ pyrolysis and then acid treatment. Additional date for same cadaver: SI-1656, $1550 \pm 70$ (personal commun). (MRZ): frozen for $1600 \mathrm{yr}$, cadaver allowed unique opportunity for radiocarbon dating human tissue. Tissues were extremely well preserved, indicating body was frozen since death. Individual was elderly woman who appears to have suffered accidental inhumation, as distal air passages were packed with aspirated sod. Post-mortem exam also revealed coronary artery disease and chronic fungal infection (id in progress). Microscopic exam confirmed suffocation as cause of death.

\section{Feniak Lake series}

Feniak Lake site is $.8 \mathrm{~km} \mathrm{~N}$ of $\mathrm{SE}$ corner of Feniak Lake, USGS Howard Pass Quadrangle, Noatak drainage, N Alaska $\left(68^{\circ} 14^{\prime} \mathrm{N}, 158^{\circ}\right.$ $\left.16^{\prime} \mathrm{W}\right)$. Site contains lst known winter house from $\mathrm{N}$ Alaska interior, relating to well-known Ipiutak culture. Cultural finds are abundant, consisting of over 1200 recognizable artifacts, all assoc with single house. Lithic inventory is identical to that found at Point Hope Ipiutak site, but organic artifact types are almost completely dissimilar, suggesting differential Ipiutak winter/summer tools (assuming that Point Hope represents a summer Ipiutak sta) or regional variation. Samples coll 1972 and subm by E S Hall, Jr, State Univ New York at Brockport, Brockport, New York (1972; Anderson, 1968; Campbell, 1962; Giddings, 1967; Irving, 1962, 1964; Larsen, 1955, 1968; Larsen and Rainey, 1948; Rainey, 1971). 
P.2056. Sample A

MASCA corrected date: $400 \pm 60 B C$

Sample A, from flooring, composed of small twigs (probably Salix) assoc with cultural material typical of site. Comment: $\mathrm{NaOH}$ pretreatment.

\section{P-2057. Sample B}

$1960 \pm 50$

10 BC

$M A S C A$ corrected date: $A D$ 50-30 \pm 60

Sample B, House wall Post F (probably Picea). Comment (ESH): house is of form not previously known for Ipiutak, though archaeol evidence strongly indicates house is directly assoc with Ipiutak cultural material.

\section{P-2058. Sample C}

$1570 \pm 50$

AD 380

MASCA corrected date: $A D 400 \pm 60$

Sample C, flooring composed of small twigs (probably Salix), ca $1.8 \mathrm{~m}$ from Sample A.

\section{P-2143. Sample E}

$$
1530 \pm 50
$$

AD 420

MASCA corrected date: $A D 440 \pm 60$

Sample E, house fill consisting of bark (Betula and fragments of Picea). Comment: $\mathrm{NaOH}$ pretreatment.

P-2143-A. Sample E

$1530 \pm 50$

AD 420

MASCA corrected date: $A D 440 \pm 60$

Sample E. Comment: same as P-2143, above, but no $\mathrm{NaOH}$ pretreatment.

\section{P-2144. Sample F7}

$$
1320 \pm 50
$$

\section{AD 630}

MASCA corrected date: $A D 650 \pm 60$

Sample F7 (probably Picea), from construction features mainly along house wall in floor fill. Comment: $\mathrm{NaOH}$ pretreatment.

\section{P-2145. Sample G}

$1360 \pm 40$ AD 590

MASCA corrected date: $A D 620 \pm 50$

Sample G, bark (Betula and fragments of Picea). Comment: $\mathrm{NaOH}$ pretreatment.

\section{Onion Portage series}

Onion Portage is a strat archaeol site on Kobuk R, NW Alaska $\left(67^{\circ} 10^{\prime} \mathrm{N}, 158^{\circ} 30^{\prime} \mathrm{W}\right)$, comprising $>70$ distinct cultural layers. Site has complex depositional history spanning ca 10,000 yr of occupation, combining varve-like flood deposits, storm-derived aeolian deposits, and thick colluvial deposits, in addition to culturally derived materials. Organic preservation is mostly poor, and occupation horizons are marked 
by thin continuous layers of charcoal, but no organic middens. Faunal remains are scarce, except for "yellowish" stains embedded in cultural strata. Cultural layers are sorted into tight clusters called bands, separated by thick colluvia derived from gullying activity on hillside immediately $\mathrm{N}$ of site. Interband colluvium decreases in thickness toward river edge. A levee of alternating silt and sand has built up along river edge of site. Separation of occupation levels is greatest on levee and strat units are numbered from secs from this area. In some cases occupation levels merge in higher part of site to $\mathrm{N}$.

Bands 1 to 8 are numbered from top to bottom; occupation levels within each band are also numbered from top to bottom. Cultural and temporal gaps between deposition units indicate that deposits occurred at irregular rate. Samples coll 1961, 1964; subm by J L Giddings. Samples coll 1965, 1966; subm by D D Anderson, Brown Univ, Providence, Rhode Island (1968, 1970a, b, c; Giddings, 1952, 1962, 1965, 1967; Hamilton, 1970).

Band 1: Arctic Woodland Eskimos

P-593-A. House 5

$920 \pm 50$

AD 1030

MASCA corrected date: $A D$ 1040 \pm 70

Charcoal from floor of House 5, probably Eksaevik phase, coll 1961 (Giddings, 1952). Comments: $\mathrm{NaOH}$ pretreatment. Rootlets removed by hand. (DDA): date probably too early.

\section{P.1112. House 13}

$900 \pm 50$

AD 1050

MASCA corrected date: $A D 1060 \pm 60$

Wood from floor of House 13, probably early Ahteut phase, coll 1965. Comment: $\mathrm{NaOH}$ pretreatment.

\section{P.1064. House 13}

$$
1490 \pm 50
$$

AD 460

MASCA corrected date: $A D$ 530-490 \pm 60

Wood from charcoal from floor of House 13, probably early Ahteut phase; coll 1965. Comments: $\mathrm{NaOH}$ pretreatment. Rootlets removed by hand. (DDA): date probably too early.

Band 2: Levels 1 to 4 are Itillik complex, Levels 5 to 12 are Ipiutak or Norton related.

\section{P-594-A. Band 2}

$$
1380 \pm 60
$$

AD 570

$M A S C A$ corrected date: $A D 600 \pm 70$

Charcoal from one of lower levels, Band 2, coll 1961. Comment: $\mathrm{NaOH}$ pretreatment.

P-1065. Band 2

$$
1570 \pm 50
$$

AD 380

MASCA corrected date: $A D 400 \pm 60$

Charcoal and sand from one of lower levels of Band 2; coll 1965. 
General Comment: other dates from Band 2: K-836, $1570 \pm 140$ (R, 1968, v 10, p 320); GX-1503, $1350 \pm 80$; GX-1502, $1440 \pm 110$ (pers commun). Band 3: Choris culture

P-1066. Band 2/3

$2370 \pm 50$ $420 \mathrm{BC}$

$M A S C A$ corrected date: $470 \pm 60 \mathrm{BC}$

Charcoal from hearth in isolated cultural level between Bands 2 and 3; coll 1965. Late Choris. Comment: $\mathrm{NaOH}$ pretreatment. Rootlets removed by hand.

\section{P-1067. Band 3, top level}

$2430 \pm 50$ MASCA corrected date: $510-540,570-660 \pm 60 \mathrm{BC}$

Charcoal and sand from hearth in top level of Band 3, coll 1965. Comment: $\mathrm{NaOH}$ pretreatment.

\section{P-591-A. Band 3}

$2450 \pm 60$ 500 вC

MASCA corrected date: $660-720 \pm 70 \mathrm{BC}$

Charcoal from upper level of Band 3, probably Level 2, coll 1961. Comment: $\mathrm{NaOH}$ pretreatment. Rootlets removed by hand.

General Comment: other dates from Band 3: upper level, K-832, 2750 \pm 140; "bottom" of Band 3, probably Level 5, K-835, $3170 \pm 120$ (R, 1968, v 10, p 320); Level 2, GX-1504, $1250 \pm 90$; Level 5, GX-1505, $1010 \pm 100$ (pers commun).

Band 4: Denbigh Flint Complex

\section{P-1068. Band 3/4}

$3530 \pm 60$

$1580 \mathrm{BC}$

$M A S C A$ corrected date: $2050 \pm 70 B C$

Charcoal and sand from isolated level between Bands 3 and 4, coll 1965. Comment: $\mathrm{NaOH}$ pretreatment. Rootlets removed by hand.

\section{$\begin{array}{ll} & 3640 \pm 60 \\ \text { P-1069-A. Band } 4 \text {, Level } 1 & 1690 \mathrm{BC}\end{array}$ \\ MASCA corrected date: $2120-2140 \pm 70 \mathrm{BC}$}

Charcoal and sand from hearth in Band 4, Level 1, Classic Denbigh; coll 1965. Comment: rootlets removed by hand.

\section{P.987. Band 4, Level 2 \\ 1910 BC}

$3860 \pm 70$

MASCA corrected date: $2350-2370,2430-2460 \pm 80 \mathrm{BC}$

Charcoal and sand from hearth in Band 4, Level 2, Glassic Denbigh; coll 1964.

\section{P-1109. Band 4, Level 3}

$3700 \pm 60$

$1750 \mathrm{BC}$

MASCA corrected date: $2160 \pm 70 \mathrm{BC}$

Charcoal and sand from hearth in Band 4, Level 3, Classic Denbigh; coll 1965. Comment: $\mathrm{NaOH}$ pretreatment. 
P.988. Band 4, Level 4

$$
3850 \pm 70
$$

$1900 \mathrm{BC}$

MASCA corrected date: $2560 \pm 80 \mathrm{BC}$

Charcoal and sand from Band 4, Level 4, Classic Denbigh; coll 1964.

P.998. Band $4 / 5$

$3950 \pm 70$

2000 BC

MASCA corrected date: $2560 \pm 80 \mathrm{BC}$

Charcoal and sand from hearth between Bands 4 and 5, Classic Denbigh; coll 1964.

Band 5: Level 1, Proto-Denbigh; Levels 2 to 3, Portage complex

\section{P.1070. Band 5, Level 1}

$3710 \pm 60$

$1760 \mathrm{BC}$

MASCA corrected date: $2160 \pm 70 \mathrm{BC}$

Charcoal and sand from house hearth, Band 5, Level 1, ProtoDenbigh; coll 1965. Comment: $\mathrm{NaOH}$ pretreatment.

\section{P-1071. Band 5, Level 1}

$3710 \pm 60$

$1760 \mathrm{BC}$

MASCA corrected date: $2160 \pm 70 B C$

Charcoal and sand from hearth in Band 5, Level 1, Proto-Denbigh; coll 1965. Comment: $\mathrm{NaOH}$ pretreatment.

\section{P-1072. Band 5, Level 2}

$4270 \pm 70$

2320 BC

MASCA corrected date: $2970-2990 \pm 80 B C$

Charcoal and soil from hearth in Band 5, Level 2, Portage complex; coll 1965 .

\section{P-1030-A. Band 5, Level 3 \\ $4340 \pm 70$ \\ 2390 BC \\ MASCA corrected date: $3110-3140 \pm 180$ BC}

Charcoal and sand from Band 5, Level 3, Portage complex; coll 1964. Comment: $\mathrm{NaOH}$ pretreatment.

\section{P-1031. Band 5, Level 3}

$4010 \pm 70$ 2060 BC

MASCA corrected date: $2610 \pm 80 B C$ 1964.

Charcoal and sand from Band 5, Level 3, Portage complex; coll

\section{P.1032. Band 5, Level 3}

$3940 \pm 70$

$1990 \mathrm{BC}$

MASCA corrected date: $2560 \pm 80 \mathrm{BC}$

Charcoal and sand from hearth in Band 5, Level 3, Portage complex; coll 1964. 


\section{P-1073. Band 5/6}

Charcoal from hearth in isolated level between Bands 5 and 6 , transition between Portage and Palisades complexes; coll 1965. Comments: undersized sample, $56.88 \%$. (DDA): date too recent.

\section{P.1110. Band 5/6}

$3200 \pm 60$

$1250 \mathrm{BC}$

MASCA corrected date: $1520-1560 \pm 70 \mathrm{BC}$

Charcoal and soil from hearth in isolated level between Bands 5 and 6, transition between Portage and Palisades complexes; coll 1965. Comment (DDA): date too recent. GX-1506, $3690 \pm 200$ (pers commun) is also too recent.

\section{P.999. Band 5/6}

$4250 \pm 60$ $2300 \mathrm{BC}$

MASCA corrected date: $2970 \pm 70 B C$

Charcoal from isolated level between Bands 5 and 6 , transition between Portage and Palisades complexes; coll 1964. Comment: $\mathrm{NaOH}$ pretreatment.

Band 6: Palisades Complex, Levels 1 to 13

\section{P-1074. Band 6, Level 1 \\ $4120 \pm 80$ \\ 2170 BC \\ MASCA corrected date: $2850 \pm 90 \mathrm{BC}$}

Charcoal and sand from hearth in Band 6, Level 1; coll 1965. Comment: $\mathrm{NaOH}$ pretreatment. Undersized sample, $83.97 \%$.

\section{$\begin{array}{cc}\text { P-1026. Band 6, Level } 7 & \mathbf{2 6 9 0} \mathbf{~ B C} \\ \text { MASCA corrected date: } 3400,3430,3470 \pm 80 \text { BC }\end{array}$}

$4640 \pm 70$

Charcoal and sand from hearth in Band 6, Level 7; coll 1964. Comment: $\mathrm{NaOH}$ pretreatment.

$\begin{array}{lr}\text { P-1075. Band 6, Level 8 } & \mathbf{5 3 2 0} \pm \mathbf{8 0} \\ & \mathbf{3 3 7 0} \mathbf{B C} \\ & \end{array}$

Charcoal and sand from hearth in Band 6, Level 8; coll 1965.

P-1027. Band 6, Level 12

$$
5110 \pm 70
$$

MASCA corrected date: $3900-3920 \pm 80$ BC

Charcoal and sand from Band 6, Level 12; coll 1964.

P.981. Band 6, Level 12

$5070 \pm 70$

3120 BC

MASCA corrected date: $3850-3880 \pm 80 \mathrm{BC}$

Charcoal and sand from hearth in Band 6, Level 12; coll 1964. 


\section{P.982. Band 6, bottom level}

MASCA corrected date: $4100,4160-4180 \pm 80 B C$

Charcoal and sand from hearth in Band 6, bottom level; coll 1964. Comment: $\mathrm{NaOH}$ pretreatment.

General Comment: other dates from Band 6: Level 13, GX-1507, $5020 \pm$ 150; lowest level, or Band 7, Level 3, GX-0261, $5680 \pm 160$ (pers commun).

Band 8: Kobuk complex

General Comment: Band 8 dates are beyond range of MASCA correction factors now available (Oct, 1974). See R, 1974, v 16, p 198-218 and Ralph et al (1973).

\section{P-984-A. Band 8, Level 1}

$7920 \pm 100$

Charcoal and sand from hearth in Band 8, Level 1; coll 1964.

\section{P.985. Band 8, Level 1}

$8100 \pm 160$

Charcoal and sand from Band 8, Level 1; coll 1964. Comment: $\mathrm{NaOH}$ pretreatment. Sample undersized, $53 \%$, diluted with anthracite.

\section{P-1076. Band 8, Level 1}

$7900 \pm 100$

Charcoal and soil from hearth in Band 8, Level 1; coll 1965. Comment: $\mathrm{NaOH}$ pretreatment.

\section{P-1111. Band 8, Level 1}

$7180 \pm 90$

5230 BC

Charcoal and soil from hearth in Band 8, Level 1; coll 1965. Comment (DDA): date too recent.

\section{P-1111-A. Band 8, Level 1}

Same as P-1111, above. Comment: $\mathrm{NaOH}$ pretreatment. (DDA): date too recent.

General Comment: other date for Band 8: Level 3, GX-1508, $8195 \pm$ 290 (pers commun).

Below Band 8: Akmak complex

General Comment: see K-1583, $9570 \pm 150$ (R, 1973, v 15, p 107).

II. GEOLOGIC SAMPLES

\section{Kobuk area peat samples}

Arctic

Peat samples from lakes near Onion Portage archaeol site (see above) on Kobuk R, NW Alaska $\left(67^{\circ} 10^{\prime} \mathrm{N}, 158^{\circ} 30^{\prime} \mathrm{W}\right)$, coll 1965 by Sten Florin; subm by D D Anderson. 


\section{P.1093. Onion Lake}

MASCA corrected date: $2950-2970 \pm 100 B C$

Peat (gyttja) from lake bed core, 205 to $215 \mathrm{~cm}$ below surface of Onion Lake, near Onion Portage. Coll 1965 by Sten Florin. Comment: undersized sample, $70.20 \%$.

\section{P-1094. Ishrakaklik Lake}

$6150 \pm 50$

$4200 \mathrm{BC}$

MASCA corrected date: $5100 \pm 60 \mathrm{BC}$

Peat (gyttja) from lake bed core, 140 to $150 \mathrm{~cm}$ below surface of Ishrakaklik Lake, NW of Onion Portage. Coll 1965 by Sten Florin.

\section{REFERENCES}

Anderson, D D, 1968, A stone age campsite at the gateway to America: Sci Am, v 218, p 24-33.

1970a, Akmak: an early archaeological assemblage from Onion Portage, Northwest Alaska: Acta Arctica, fascicle 16, p 1-80.

1970b, Athapaskans in the Kobuk Arctic woodland, Alaska?: Canadian Archaeol Assoc, Bull 2, p 3-12. v $7, \mathrm{p} 2-16$.

Bouzek, Jan, Koutecky, Drahmír, and Neustupny, Evzen, 1966, The Knovíz settlement of Northwest Bohemia: Fontes Archaeol Pragenses, v 10, p 17-18.

Campbell, J M, 1962, Cultural succession at Anaktuvuk Pass, Arctic, Alaska, in Campbell, J M (ed), Prehistoric cultural relations between the arctic and tem perate zones of North America: Washington, D C, Arctic Inst N Am, p 39-54.

Dani, A H, 1971, Gomal excavations: Ancient Pakistan, v 5, p 1-177.

French, D H, 1971, An experiment in water sieving: Anatalian Studies, v 21, p 59-64.

Giddings, J L, 1952, The Arctic woodland culture of the Kobuk River: Philadelphia, Univ Mus, p 1-143.

1962, Onion Portage and other flint sites of the Kobuk River: Arctic Anthropol, v 1, p 6-27.

1964, A long record of Eskimos and Indians at the forest edge, in: Spiro, M E (ed), Context and meaning in cultural anthropology, Riverside, $\mathrm{N} \mathrm{J}$, The Free Press, c/o MacMillan Pub Co, p 189-205.

1967, Ancient men of the Arctic: New York, Knopf, p 1-391

Hall, E S, Jr, 1972, Archaeological investigations in Northern Alaska: Summer 1972: unpub ms.

Hamilton, T D, 1970, Geologic relations of the Akmak assemblage, Onion Portage area, in: Akmak: an early archaeological assemblage from Onion Portage, North west Alaska: Acta Arctica, fascicle 16, p 71-78.

Irving, W N, 1962, Fieldwork in the Western Brooks range: prelim rept: Arctic Anthropol, v 1, p 76-87. Wisconsin.

Jacobsen, T W, 1968, Investigations at Porto Cheli-Halieis, 1967: Archaiol Deltion, v 23, p 144-148.

1969a, Investigations at Porto Cheli, 1968: Archaiol Deltion, v 24, p 135-139. 1969b, The Franchthi cave: Archaeol, v 22, no. 1, p 4-9.

1969c, Excavations at Porto Cheli and vicinity, prelim rept, II: the Franchthi cave: Hesperia, v 38 , no. 3 , p 348-381.

1973, Excavations in the Franchthi cave, 1969-1971, pt I: Hesperia, v 42, no. $1, \mathrm{p} 45-88$.

Jameson, M H, 1969, Excavations at Porto Cheli and vicinity, prelim rept, I: Halieis, 1962-1968: Hesperia, v 38, p 311-342.

1973, Halieis at Porto Cheli, in Blackman, D J (ed), Marine Archaeology: Hamden, Connecticut, Archon Books, p 219-229.

Kadish, Barbara, 1969, Excavations of prehistoric remains at Aphrodisias, 1967: Am Jour Archaeol, v 73, p 49-65. 
Kadish, Barbara, 1971, Excavations of prehistoric remains at Aphrodisias, 1968 \& 1969: Am Jour Archaeol, v 75, p 122-140. Kosay, Hâmit, 1970, 1968 summer work: Middle East Tech Univ-Keban Proj pub
ser I, no. 1, p 139-146.

Larsen, Helge, 1955, Recent developments in Eskimo archaeology, in: Actes IV Cong internatl anthropol et ethnol, Vienna, Sept 1-8, 1952: Vienna, Holhausers Nfg. 1968, Trail Creek: Acta Arctica, fascicle 15, 1-80.

Larsen, Helge and Rainey, Froelich, 1948, Ipiutak and the Arctic whale hunting culture: Anthropol Papers Am Mus Nat History, v 42, p 1-276.

Lawn, Barbara, 1971, University of Pennsylvania radiocarbon dates XIV: Radiocarbon, v 13, p 363-377. v 15, p 1973, University of Pennsylvania radiocarbon dates XV: Radiocarbon, v 16, p 219-237. XVI: Radiocarbon, v 16, p 198-218.

Özgüc, Nimet, 1968, New light on the dating of the levels of the Karem of Kanish and of Acem Höyük near Aksaray: Am Jour Archaeol, v 72, p 318-320.

Platon, N E, 1971, Zakros, the discovery of a lost palace of ancient Crete: New York, Scribner, p 1-345.

Rainey, Froelich, 1971, The Ipiutak culture: excavations at Point Hope, Alaska: Current topics in Anthropol, v 2, p 1-42.

Ralph, E K, Michael, H N, and Han, M C, 1973, Radiocarbon dates and reality: MASCA Newsletter, v 9, no. 1, p 1-20.

Tauber, Henrik, 1968, Copenhagen radiocarbon dates IX: Radiocarbon, v 10, p 295-327. 